\title{
Association between estrogen receptor alpha gene polymorphisms and bone mineral density in Polish female patients with Graves' disease
}

\author{
Magdalena Ignaszak-Szczepaniak ${ }^{1,2} \bowtie$, Wanda Horst-Sikorska ${ }^{1,2}$, Joanna Dytfeld ${ }^{1,2}$, \\ Michalina Marcinkowska ${ }^{2}$, Ewelina Gowin ${ }^{2}$, Ryszard Słomski ${ }^{3,4^{\prime}}$ and Marek Stajgis ${ }^{5}$
}

${ }^{1}$ Center of Metabolic Bone Diseases, ${ }^{2}$ Department of Family Medicine, ${ }^{5}$ Department of Radiology, Poznan University of Medical Sciences, Poznań, Poland; ${ }^{3}$ Department of Biochemistry and Biotechnology, Poznan University of Agriculture, Poznań, Poland; ${ }^{4}$ Institute of Human Genetics, Polish Academy of Sciences, Poznań, Poland

Graves' (GD) hyperthyroidism leads to reduced bone mineral density (BMD) accompanied by accelerated bone turnover. Ample studies have identified association between estrogen receptor (ESR1) gene polymorphism and decreased BMD and osteoporosis. In contrast, number of publications that link ESR1, BMD and Graves' disease is limited. The purpose of this study was to identify the association between ESR1 polymorphisms and BMD in premenopausal women with GD and to determine whether ESR1 polymorphic variants can predispose to GD. The study included 75 women aged 23-46 years with GD and 163 healthy controls. BMD was measured at lumbar spine and femoral neck. We investigated two SNPs in the ESR1 gene and analyzed genetic variants in the form of haplotypes reconstructed by statistical method. Three out of four possible haplotypes of the Pvull and Xbal restriction fragment length polymorphisms were found in GD patients: px (55.3\%), PX (33.3\%) and Px (11.4\%). Women homozygous for xx of Xbal and for pp of Pvull had the lowest BMD at lumbar spine. Moreover, the px haplotype predisposed to reduced lumbar BMD. No associations were observed for femoral neck BMD. No statistically significant relationship were found between ESR1 polymorphisms or their haplotypes and GD. These results indicate that the Pvull and the Xbal polymorphisms of ESR1 gene are associated with bone mineral density in premenopausal women with GD and may help to estimate the risk of bone loss particularly at lumbar spine. However, none of the ESR1 gene alleles predict the risk of GD in Polish female patients.

Keywords: ESR1 gene polymorphisms, bone mineral density, Graves' disease, premenopausal women

Received: 23 August, 2010; revised: 14 December, 2010; accepted: 08 March, 2011; available on-line: 19 March, 2011

\section{INTRODUCTION}

Hyperthyroidism is diagnosed in $2 \%$ of adult population, predominantly in women. Approximately 60-80\% of cases of hyperthyroidisms are due to Graves' disease (GD) that tends to affect women in their third and fourth decade of life. This autoimmune, chronic disease has recurrent nature and affects many tissues, including bone. The disease has a strong genetic background associated with polymorphisms in the HLA and CTL $A-4$ (cytotoxic T lymphocyte associated 4 genes (Donner et al., 1997).
Hyperthyroidism disturbs bone metabolism and is an important risk factor for secondary osteoporosis. The pathophysiology is multifactorial. An excess of thyroid hormones induces both acceleration of bone turnover due to an increased number of active osteoclasts, increased osteoblasts activity and shortening of the bone remodeling cycle (Eriksen et al., 1995; Murphy \& Wiliams, 2004). This kind of bone damage is usually reversible. The duration of exposure to an excess of thyroid hormones is a major factor determining bone condition. The longer the time of hyperthyroidism, the greater decrease of bone mass. Normalization of bone status usually takes 6-12 months after achieving euthyreosis. Biochemical markers of bone metabolism come to normal ranges sooner, usually within 6 months (Diamond et al., 1994). A BMD (bone mineral density) reduction in the axial skeleton is observed irrespective of gender. Higher incidence of osteoporosis in women concerns both primary and hyperthyroidism-related osteoporosis. Here, age is the most important factor for bone quality, because estrogen status has a strong influence on bone turnover. Thus, hyperthyroid premenopausal females without an estrogen deficiency are an adequate group to estimate the influence of high level of thyroid hormones and autoimmune process on bone density (Diamond et al., 1994).

Bone mineral density is determined by large number of genes. The influence of genetic factors on bone metabolism and fracture risk has already been investigated widely.

Considering the important role of estrogens in bone turnover and their protective effect on BMD, numerous studies have targeted estrogen receptor alpha (ESR1) gene, in particular its polymorphisms defined by the restriction enzymes $X b a \mathrm{I}$ and PvuII, to evaluate its association with bone mineral density. However, the results are inconsistent and the effects of these two polymorphisms on BMD and fracture risk remain ambiguous (Ioannidis et al., 2002; Yamada et al., 2002; van Meurs et al., 2003; Ioannidis et al., 2004). Estrogen receptor also modulates the transcription of target genes in response to estrogens, which appears to play an important role in immune response and immunemediated diseases (Cutolo et al., 1995).

e-mail: maszczep@ump.edu.pl

Abbreviations: BMD, bone mineral density; ESR1, estrogen receptor alpha; FN, femoral neck; GD, Graves' disease; LS, lumbar spine 
We have recently showed that some polymorphic variants of another candidate gene - VDR (vitamin D receptor) - may predispose women to Graves' disease, but do not predict the risk of reduced BMD in these patients (Horst-Sikorska et al., 2008).

In view of the possible role of estrogens in the pathogenesis of GD as well as their effect on BMD, the aim of this study was to identify the relationship between the ESR1 polymorphisms and bone mineral density in premenopausal women with Graves' and to determine whether ESR1 polymorphic variants predispose females to the autoimmune disease of the thyroid gland.

\section{MATERIALS AND METHODS}

Patients were recruited from the Outpatient Endocrinology Clinic of District Hospital in Poznań. The study group comprised 75 premenopausal women 26-46 years old (average age 37 years) previously diagnosed with Graves' disease. Patients were checked for past medical history, underwent physical examination, and a variety of laboratory parameters (see below) and bone mineral density were measured. They did not report relevant complaints regarding the central skeleton, fractures, or loss of height, and regularly menstruating at the time of the study. The study group was homogenous for physical activity (below $2 \mathrm{~h}$ weekly), smoking habits (non-smokers) and alcohol consumption (less than 1 unit daily). Family history of osteoporotic fractures was not analyzed. The presence of significant co-morbidities influencing bone metabolism (e.g., hyperparathyroidism, diabetes mellitus, renal failure, hematological diseases, severe gastroenterological disorders) was a reason for exclusion from the study.

Laboratory tests to assess the patients' endocrine status, recommended at the beginning of the study, included free thyroxine (fT4; normal range: 11.5-21 $\mathrm{pmol} / \mathrm{L}$ ), free triiodothyronine (fT3; normal range: 3.95$6.3 \mathrm{pmol} / \mathrm{L}$ ), thyroid-stimulating hormone ( $\mathrm{TSH}$; normal range: $0.27-4.2 \mathrm{mU} / \mathrm{L}$ ) and TSH-receptor antibodies (TSHRAb; normal range: $<2 \mathrm{IU} / \mathrm{L}$ ). The diagnosis of GD hyperthyroidism was established by the presence of clinical symptoms, elevated fT4 and/or fT3 with decreased TSH serum concentrations together with elevated level of TSHRAb.

Patients were divided into two groups on the basis of thyroid function. The first group comprised both women freshly diagnosed with overt hypertyroidism and patients with the TSH level normalized for less than 3 months. Women whose serum TSH level had remained within normal ranges for over 12 months formed the other group of patients. In those patients active hyperthyroidism, confirmed by lab tests, had lasted for 3-9 months.

Bone mineral density was assessed by dual energy X-ray absorptiometry (DEXA) with a Lunar DPX-
Plus device calibrated with a spine phantom. The BMD measurements concerned lumbar spine (LS, vertebrae L1-L4) and femoral neck (FN). Osteoporosis was defined as a T-score below -2.5SD according to WHO criteria (Kanis, 2007). The results of BMD measurements were interpreted with emphasis on the differences between particular genotypes and haplotypes.

The control group consisted of 163 healthy unrelated females aged 47-89 years (average 65 years), with no personal or family history of autoimmune diseases. Older women were chosen as controls deliberately, due to generally lower incidence of autoimmune disease, particularly GD, in older population. Each subject was given written informed consent.

The study was approved by the local ethics committee.

Genotyping. The analysis of polymorphisms in the first intron of ESR1 gene was performed for GD patients and the controls. Genomic DNA was isolated from peripheral blood by the standard method with guanidine izotiocyanate (GTC) and analyzed by the method reported by Yaich et al. (1992) and Kobayashi et al. (1996) with own modification. Genomic DNA (200 $\mathrm{ng}$ ) was amplified in $20 \mu \mathrm{l}$ of buffer solution $(50 \mathrm{mM} \mathrm{KCl}, 10 \mathrm{mM}$ Tris $/ \mathrm{HCl}, \mathrm{pH} 8.3,1.5 \mathrm{mM}$ $\mathrm{MgCl}_{2}, 0.25 \mathrm{mM} \mathrm{dNTP}$ ). Taq polymerase (0.5 unit; Sigma) and 7.5 pmol of each oligonucleotide primer. PCR reaction was performed for 30 cycles with the following steps: denaturation at $94^{\circ} \mathrm{C}$ for $40 \mathrm{~s}$, annealing at $57^{\circ} \mathrm{C}$ for $40 \mathrm{~s}$ and extension at $72^{\circ} \mathrm{C}$ for 100 s. PCR product was digested with PvuII and XbaI restriction endonucleases (Fermentas) for restriction fragment length polymorphism (RFLP) analysis. Products of digestion were separated in 1.5\% agarose gels and stained with ethidium bromide. The possible genotypes were: PP, Pp, pp for PvuII and XX, Xx, xx for $X b a \mathrm{I}$, where $\mathrm{P}$ and $\mathrm{X}$ denote the absence, while $\mathrm{p}$ and $\mathrm{x}$ the presence of the restriction sites.

Statistical analysis. Student's t-test was used to compare the means of two samples. To check whether data follow normal distribution Shapiro-Wilks test was used. The assumption of homogeneity of variances was analyzed by F test. Relationships between BMD and clinical parameters - age, body mass, weight and height — were analyzed by Spearman's rank correlation coefficient (Statistica v.6.0, StatSoft). Analysis of the compliance of distribution of genotypes and haplogenotypes with the distribution in the Hardy-Weinberg equilibrium was carried out by a program available at http://ihg.gsf.de/cgi-bin/hw/hwa1.pl. HardyWeinberg equilibrium was found for all the polymorphisms and haplogenotypes analyzed. The analysis of the linkage disequilibrium (LD) of examined polymorphisms was performed with the assistance of the Haploview v. 3.11 program available on www.broad. mit.edu/mpg/haploview/index.php. This method was used to provide a D prime (D') value. A D' value of

Table 1. Polymorphisms in the ESR1 and methods of their genotyping methodical nomenclature recommended by Human Genome Variation Society (www.hgvs.org)

\begin{tabular}{lllll}
\hline \multirow{2}{*}{ Gene } & \multicolumn{2}{l}{ Analyzed polymorphisms } & & Method used for genotyping \\
\cline { 2 - 5 } & $\begin{array}{l}\text { SNP number } \\
\text { (db SNP) }\end{array}$ & $\begin{array}{l}\text { Common nomenclature used in paper } \\
\text { (alleles) }\end{array}$ & Methological nomenclature & \\
\cline { 2 - 5 } & rs2234693 & Pvull $(\mathrm{p} \mathrm{P})$ & $c .453-397 T>C$ & RFLP (restriction endonuclease Pvull) \\
& rs9340799 & Xbal $(\mathrm{x} \mathrm{X)}$ & $c .453-351 \mathrm{~A}>\mathrm{G}$ & RFLP (restriction endonuclease Xbal) \\
\hline
\end{tabular}


Table 2. Mean BMD values in studied group

\begin{tabular}{lcc}
\hline & $\begin{array}{c}\text { mean value for } \\
\text { FN BMD }\left(\mathrm{g} / \mathrm{cm}^{2}\right)\end{array}$ & $\begin{array}{c}\text { mean value for } \\
\text { LS BMD }\left(\mathrm{g} / \mathrm{cm}^{2}\right)\end{array}$ \\
\hline $\begin{array}{l}\text { hyperthyroidism or } \\
<\text { 3-month euthyreosis; } \mathrm{n}=39\end{array}$ & $0.971 \pm 0.054$ & $1.154 \pm 0.125$ \\
$\begin{array}{l}\text { over 12-month euthyreosis; } \\
\mathrm{n}=36\end{array}$ & $1.004 \pm 0.025$ & $1.198 \pm 0.109$ \\
$P$ value & 0.178 & 0.529 \\
\hline
\end{tabular}

0 indicates no LD between different polymorphisms, and D' value of 1 indicates complete LD.

Association analysis was performed for three possible effects of the influence of a given polymorphism: allele dose effect, effect of recessiveness and effect of dominance. Bone mineral density was considered as non-adjusted and adjusted by: age, body mass and height of subjects. The significance was calculated using the analysis of variance (ANOVA). For post-hoc analysis Tukey test was used. The impact of allele or haplotype dose on BMD was analyzed by simple regression (non-adjusted BMD) or multiple regression (adjusted BMD). In addition, an analysis of associations (case-control type) of ESR1 gene polymorphisms with Graves' disease development was done. It was carried out for the following three possible effects of action: the allele dose (c2 Armitage test for trend), recessive and dominant action (c2 Person's and odds ratio for a significant value of $\mathrm{c} 2$ test only). All tests were analysed at the significance level of $a=0.05$, and the analyses were performed using STATISTICA v. 6.0 (StatSoft Inc., http://www.statsoft.com).

\section{RESULTS}

Densitometric parameters at femoral neck (FN) and lumbar spine (LS) were analyzed in GD patients. Mean LS BMD was $1.172 \mathrm{~g} / \mathrm{cm}^{2}$ and mean FN BMD was $0.985 \mathrm{~g} / \mathrm{cm}^{2}$ for the whole group. Only $2 \%$ of patients fulfilled the densitometric criteria of osteoporosis with a T-score below -2.5SD. A comparison of BMD between women with overt hyperthyroidism ( $\downarrow T S H, \uparrow f T 4)$ or short-lasting euthyreosis (normalized TSH and fT4) and those euthyreotic for longer than 12 months showed a non-significant dependence of BMD values at both lumbar spine and femoral neck on the duration of hyperthyroidism regression.

The BMD values were lower in the group of patients with decreased TSH or TSH normalized for less than 3 months than in the group with normalized TSH for at least 12 months (see Table 2).

Spearman's rank correlation analysis showed correlations between body mass and height and both LS and FN BMD. The age gave a significant negative correlation only with FN BMD. Results are presented in Table 3.

Table 3. Spearman's rank correlation analysis between anthropometric parameters and FN/LS BMD

\begin{tabular}{lcccc}
\hline & \multicolumn{2}{c}{ FN BMD } & \multicolumn{2}{c}{ LS BMD } \\
\hline & $\begin{array}{c}\text { Spearman's rank cor- } \\
\text { relation coefficient }\end{array}$ & $P$ & $\begin{array}{c}\text { Spearman's rank cor- } \\
\text { relation coefficient }\end{array}$ & $P$ \\
\hline Age & $r=-0.235$ & 0.043 & $r=-0.124$ & 0.29 \\
Body mass & $r=0.282$ & 0.014 & $r=0.333$ & 0.004 \\
Height & $r=0.308$ & 0.007 & $r=0.262$ & 0.023 \\
\hline
\end{tabular}
haplotype px of ESR1 gene. of association between LS and FN BMD in relation to

A dose effect was observed for the PX haplotype. Women homozygous for PX had the highest adjusted LS BMD $\left(1.248 \mathrm{~g} / \mathrm{cm}^{2}\right)$ as opposed to non carriers of this haplotype who had the lowest non- and adjusted LS BMD $\left(1.113 \mathrm{~g} / \mathrm{cm}^{2}\right)$. The effect was staistically significant $(P=0.023)$. Also the effect of dominance was noted for this haplotype. Women without the PX haplotype had a lower adjusted LS BMD (1.130 g/ $\left.\mathrm{cm}^{2}\right)$ than women with the PX haplotype on one or
both chromosomes $\left(1.203 \mathrm{~g} / \mathrm{cm}^{2}, P=0.049\right)$. Table 6 contains the results of analysis of the association between LS and FN BMD with haplotype PX of ESR1 gene. There was no influence for femoral neck BMD.

The third most frequent haplotype (Px) had no statistically sig- 
Table 4. Distribution of ESR1 gene polymorphisms and their association analysis

\begin{tabular}{|c|c|c|c|c|c|c|c|c|c|c|c|}
\hline & & \multicolumn{2}{|c|}{$\begin{array}{l}\text { Number of } \\
\text { subjects } \\
(\mathrm{n})\end{array}$} & \multicolumn{2}{|c|}{$\begin{array}{l}\text { Non-adjusted BMD } \\
\text { value for FN } \\
\left(\mathrm{g} / \mathrm{cm}^{2}\right)\end{array}$} & \multicolumn{2}{|c|}{$\begin{array}{l}\text { Adjusted BMD } \\
\text { value for FN } \\
\left(\mathrm{g} / \mathrm{cm}^{2}\right)\end{array}$} & \multicolumn{2}{|c|}{$\begin{array}{l}\text { Non-adjusted BMD } \\
\text { value for LS } \\
\left(\mathrm{g} / \mathrm{cm}^{2}\right)\end{array}$} & \multicolumn{2}{|c|}{$\begin{array}{l}\text { Adjusted BMD } \\
\text { value for LS } \\
\left(\mathrm{g} / \mathrm{cm}^{2}\right)\end{array}$} \\
\hline \multicolumn{12}{|l|}{ ESR1 Xbal } \\
\hline \multicolumn{2}{|l|}{ Allele dose effect } & \multicolumn{2}{|c|}{$\mathrm{n}=75$} & \multirow[b]{2}{*}{1.002} & \multirow[b]{2}{*}{ \pm 0.154} & \multirow[b]{2}{*}{0.976} & \multirow[b]{2}{*}{ \pm 0.133} & \multirow[b]{2}{*}{1.265} & \multirow[b]{2}{*}{ \pm 0.205} & \multirow[b]{2}{*}{1.248} & \multirow[b]{2}{*}{ \pm 0.143} \\
\hline Allele dose & $X X$ & 9 & $12.0 \%$ & & & & & & & & \\
\hline & $X x$ & 32 & $42.7 \%$ & 0.990 & \pm 0.140 & 0.994 & \pm 0.138 & 1.171 & \pm 0.138 & 1.190 & \pm 0.148 \\
\hline & $x x$ & 34 & $45.3 \%$ & 0.967 & \pm 0.151 & 0.970 & \pm 0.139 & 1.144 & \pm 0.163 & 1.113 & \pm 0.149 \\
\hline Significance & & & & \multicolumn{2}{|c|}{$P=0.437$} & \multicolumn{2}{|c|}{$P=0.726$} & \multicolumn{2}{|c|}{$P=0.066$} & \multicolumn{2}{|c|}{$P=0.023$} \\
\hline \multicolumn{12}{|c|}{ Effects of recessiveness and dominance } \\
\hline \multirow[t]{2}{*}{ Genotype } & $X X+X x$ & 41 & $54.7 \%$ & 0.993 & \pm 0.141 & 0.990 & \pm 0.137 & 1.192 & \pm 0.157 & 1.203 & \pm 0.148 \\
\hline & $x x$ & 34 & $45.3 \%$ & 0.967 & \pm 0.151 & 0.970 & \pm 0.138 & 1.144 & \pm 0.163 & 1.130 & \pm 0.150 \\
\hline Significance & & & & $P=0.4$ & & $P=0.5$ & & $P=0.2$ & & $P=0.0$ & \\
\hline \multirow[t]{2}{*}{ Genotype } & $X X$ & 9 & $12.0 \%$ & 1.002 & \pm 0.154 & 0.975 & \pm 0.131 & 1.265 & \pm 0.205 & 1.245 & \pm 0.145 \\
\hline & $X x+x x$ & 66 & $88.0 \%$ & 0.978 & \pm 0.145 & 0.982 & \pm 0.134 & 1.157 & \pm 0.151 & 1.160 & \pm 0.142 \\
\hline Significance & & & & \multicolumn{2}{|c|}{$P=0.644$} & \multicolumn{2}{|c|}{$P=0.887$} & \multicolumn{2}{|c|}{$P=0.058$} & \multicolumn{2}{|c|}{$P=0.104$} \\
\hline \multicolumn{12}{|l|}{ ESR1 Pvull } \\
\hline \multicolumn{2}{|l|}{ Allele dose effect } & \multicolumn{2}{|c|}{$n=75$} & & & & & & & & \\
\hline Allele dose & PP & 13 & $17.3 \%$ & 0.983 & \pm 0.133 & 0.963 & \pm 0.133 & 1.206 & \pm 0.199 & 1.199 & \pm 0.144 \\
\hline & $\mathrm{Pp}$ & 41 & $54.7 \%$ & 0.990 & \pm 0.142 & 0.997 & \pm 0.131 & 1.182 & \pm 0.151 & 1.190 & \pm 0.142 \\
\hline & $\mathrm{pp}$ & 21 & $28.0 \%$ & 0.962 & \pm 0.162 & 0.961 & \pm 0.134 & 1.126 & \pm 0.149 & 1.113 & \pm 0.146 \\
\hline Significance & & & & $P=0.6$ & & $P=0.8$ & & $P=0.1$ & & $P=0.0$ & \\
\hline Effects of recessiv & eness a & domi & & & & & & & & & \\
\hline Genotype & $P P+P p$ & 54 & $72.0 \%$ & 0.989 & \pm 0.139 & 0.989 & \pm 0.131 & 1.187 & \pm 0.162 & 1.192 & \pm 0.142 \\
\hline & $\mathrm{pp}$ & 21 & $28.0 \%$ & 0.962 & \pm 0.162 & 0.961 & \pm 0.134 & 1.126 & \pm 0.149 & 1.113 & \pm 0.145 \\
\hline Significance & & & & $P=0.4$ & & $P=0.4$ & & $P=0.1$ & & $P=0.0$ & \\
\hline Genotype & PP & 13 & $17.3 \%$ & 0.983 & \pm 0.133 & 0.962 & \pm 0.133 & 1.206 & \pm 0.199 & 1.197 & \pm 0.147 \\
\hline & $P p+p p$ & 62 & $82.7 \%$ & 0.981 & \pm 0.148 & 0.985 & \pm 0.131 & 1.163 & \pm 0.152 & 1.165 & \pm 0.145 \\
\hline Significance & & & & $P=0 . \subseteq$ & & $P=0.5$ & & $P=0.3$ & & $P=0.4$ & \\
\hline
\end{tabular}

nificant association with bone mineral density neither for femoral neck or lumbar spine (see Table 7).

\section{A case-control study}

A case-control analysis of association with predisposition to GD was performed for the ESR1 polymorphisms (PvuII, XbaI) and their haplotypes. The most frequent genotype was Pp of PvuII for both GD patients and the controls. When the XbaI was tested, the $\mathrm{Xx}$ genotype was the most frequent in the controls while $\mathrm{xx}$ in women with Graves' (see Table 8). The distribution of the px, PX, and Px haplotypes among the Graves' patients and the control group is shown in Table 9.

No statistically significant associations with the autoimmune disease were found for ESR1 polymorphisms studied or for their haplotypes. The lack of an association found may be caused by low power of performed tests (the power of particular comparisons varied from $12 \%$ to $87 \%$ ) or may not occur at all.

\section{DISCUSSION}

The main purpose of the present study was to look for a relationship between the ESR1 gene polymorphisms and BMD as an indicator of osteoporosis in Graves' patients. The second aim was to find out whether the ESR1 polymorphic variants predispose premenopausal women to this autoimmune disease of the thyroid gland.

Many studies have identified an association between the ESR1 genotype and decreased BMD or osteoporosis. Bone loss in Graves' patients has been also shown in several studies suggesting an impact of autoimmunity on bone turnover. However, the number of publications that link ESR1, BMD and Graves' disease is small. Here, we tried to answer the question about possible association 
Table 5. Association analysis of haplotype px of ESR1 gene with BMD for FN and LS

\begin{tabular}{|c|c|c|c|c|c|c|c|c|c|c|c|}
\hline \multirow{2}{*}{\multicolumn{2}{|c|}{$\begin{array}{l}\text { ESR1 px } \\
\text { Dose effect of haplotype }\end{array}$}} & \multicolumn{2}{|c|}{$\begin{array}{l}\text { Number of } \\
\text { samples } \\
\text { (n) }\end{array}$} & \multicolumn{2}{|c|}{$\begin{array}{l}\text { Non-adjusted BMD } \\
\text { value for FN } \\
\left(\mathrm{g} / \mathrm{cm}^{2}\right)\end{array}$} & \multicolumn{2}{|c|}{$\begin{array}{l}\text { Adjusted BMD value } \\
\text { for FN } \\
\left(\mathrm{g} / \mathrm{cm}^{2}\right)\end{array}$} & \multicolumn{2}{|c|}{$\begin{array}{l}\text { Non-adjusted } \\
\text { BMD value for } L S \\
\left(\mathrm{~g} / \mathrm{cm}^{2}\right)\end{array}$} & \multicolumn{2}{|c|}{$\begin{array}{l}\text { Adjusted BMD } \\
\text { value for LS } \\
\left(\mathrm{g} / \mathrm{cm}^{2}\right)\end{array}$} \\
\hline & & $\mathrm{n}=$ & & & & & & & & & \\
\hline \multirow[t]{3}{*}{ Haplotype dose } & 0 & 13 & $17.3 \%$ & 0.983 & \pm 0.133 & 0.963 & \pm 0.133 & 1.206 & \pm 0.199 & 1.199 & \pm 0.144 \\
\hline & 1 & 41 & $54.7 \%$ & 0.990 & \pm 0.142 & 0.997 & \pm 0.131 & 1.182 & \pm 0.151 & 1.190 & \pm 0.142 \\
\hline & 2 & 21 & $28.0 \%$ & 0.962 & \pm 0.162 & 0.961 & \pm 0.134 & 1.126 & \pm 0.149 & 1.113 & \pm 0.146 \\
\hline \multicolumn{4}{|l|}{ Significance } & \multicolumn{2}{|c|}{$P=0.615$} & \multicolumn{2}{|c|}{$P=0.833$} & \multicolumn{2}{|c|}{$P=0.133$} & \multicolumn{2}{|c|}{$P=0.070$} \\
\hline \multicolumn{12}{|c|}{ Effects of recessiveness and dominance } \\
\hline \multirow[t]{2}{*}{ Genotype } & $0+1$ & 54 & $72.0 \%$ & 0.989 & \pm 0.139 & 0.989 & \pm 0.131 & 1.187 & \pm 0.162 & 1.192 & \pm 0.142 \\
\hline & 2 & 21 & $28.0 \%$ & 0.962 & \pm 0.162 & 0.961 & \pm 0.134 & 1.126 & \pm 0.149 & 1.113 & \pm 0.145 \\
\hline Significance & & & & \multicolumn{2}{|c|}{$P=0.479$} & \multicolumn{2}{|c|}{$P=0.424$} & \multicolumn{2}{|c|}{$P=0.137$} & \multicolumn{2}{|c|}{$P=0.039$} \\
\hline \multirow[t]{2}{*}{ Genotype } & 0 & 13 & $17.3 \%$ & 0.983 & \pm 0.133 & 0.962 & \pm 0.133 & 1.206 & \pm 0.199 & 1.197 & \pm 0.147 \\
\hline & $1+2$ & 62 & $82.7 \%$ & 0.981 & \pm 0.148 & 0.985 & \pm 0.131 & 1.163 & \pm 0.152 & 1.165 & \pm 0.145 \\
\hline Significance & & & & \multicolumn{2}{|c|}{$P=0.965$} & \multicolumn{2}{|c|}{$P=0.570$} & \multicolumn{2}{|c|}{$P=0.384$} & \multicolumn{2}{|c|}{$P=0.474$} \\
\hline
\end{tabular}

between ESR1 polymorphisms and bone mineral density in the context of autoimmune processes underlying GD. This is why two aspects were considered: the influence of hyperthyroidism on bone and impact of ESR1 polymorphic variants on bone mineral density.

The present study investigated premenopausal, regularly menstruating women with a similar lifestyle without any other diseases affecting bone metabolism. This approach ensured that estrogen deficiency, one of the most important factors for osteoporosis, was eliminated. First, bone mineral density of 75 premenopausal GD women was correlated with age, body mass and height. The correlation between BMD and weight/height was positive, whereas between $\mathrm{BMD}$ and age - negative. Therefore, it was proven that the risk factors for osteoporosis established for the whole population are also valid for young women with hyperthyroidism due to GD. One of the accepted explanations of the positive relationship between weight and BMD is that body weight increases bone mass. The stronger the mechanical stress on bone, the more effective are the processes of osteosynthesis and mineralization and in consequence - higher peak bone mass (Walker-Bone et al., 2002).

However, the influence of age on BMD remains unclear. We found a negative correlation between age and FN BMD, but not LS BMD.

In our study we paid special attention to the selection of the patients. In most studies on the discussed issue addressed here, the study groups comprised much older subjects. Our females comprising the study group were younger and menstruating. This gave us the opportunity to explore other determinants of BMD than the estrogen deficit. Changes in BMD in patients with GD in our

Table 6. Association analysis of haplotype PX of ESR1 gene with BMD for FN and LS

\begin{tabular}{|c|c|c|c|c|c|c|c|c|c|c|c|}
\hline \multirow{2}{*}{\multicolumn{2}{|c|}{$\begin{array}{l}\text { ESR1 PX } \\
\text { Dose effect of haplotype }\end{array}$}} & \multicolumn{2}{|c|}{$\begin{array}{l}\text { Number of } \\
\text { samples } \\
\text { (n) }\end{array}$} & \multicolumn{2}{|c|}{$\begin{array}{l}\text { Non-adjusted BMD } \\
\text { value for FN } \\
\left(\mathrm{g} / \mathrm{cm}^{2}\right)\end{array}$} & \multicolumn{2}{|c|}{$\begin{array}{l}\text { Adjusted BMD } \\
\text { value for FN } \\
\left(\mathrm{g} / \mathrm{cm}^{2}\right)\end{array}$} & \multicolumn{2}{|c|}{$\begin{array}{l}\text { Non-adjusted BMD } \\
\text { value for LS } \\
\left(\mathrm{g} / \mathrm{cm}^{2}\right)\end{array}$} & \multicolumn{2}{|c|}{$\begin{array}{l}\text { Adjusted BMD value } \\
\text { for } \mathrm{LS} \\
\left(\mathrm{g} / \mathrm{cm}^{2}\right)\end{array}$} \\
\hline & & $\mathrm{N}=$ & & & & & & & & & \\
\hline \multirow[t]{3}{*}{ Haplotype dose } & 0 & 34 & $45.0 \%$ & 0.967 & \pm 0.151 & 0.970 & \pm 0.139 & 1.144 & \pm 0.163 & 1.113 & \pm 0.149 \\
\hline & 1 & 32 & $42.7 \%$ & 0.990 & \pm 0.140 & 0.994 & \pm 0.138 & 1.171 & \pm 0.138 & 1.190 & \pm 0.148 \\
\hline & 2 & 9 & $12.0 \%$ & 1.002 & \pm 0.154 & 0.976 & \pm 0.133 & 1.265 & \pm 0.205 & 1.248 & \pm 0.143 \\
\hline \multicolumn{4}{|l|}{ Significance } & \multicolumn{2}{|c|}{$P=0.437$} & \multicolumn{2}{|c|}{$P=0.726$} & \multicolumn{2}{|c|}{$P=0.066$} & \multicolumn{2}{|c|}{$P=0.023$} \\
\hline \multicolumn{12}{|c|}{ Effects of recessiveness and dominance } \\
\hline \multirow[t]{2}{*}{ Genotype } & $0+1$ & 66 & $88.0 \%$ & 0.978 & \pm 0.145 & 0.982 & \pm 0.131 & 1.157 & \pm 0.151 & 1.160 & \pm 0.142 \\
\hline & 2 & 9 & $12.0 \%$ & 1.002 & \pm 0.154 & 0.975 & \pm 0.133 & 1.265 & \pm 0.205 & 1.245 & \pm 0.145 \\
\hline Significance & & & & \multicolumn{2}{|c|}{$P=0.644$} & \multicolumn{2}{|c|}{$P=0.887$} & \multicolumn{2}{|c|}{$P=0.058$} & \multicolumn{2}{|c|}{$P=0.104$} \\
\hline \multirow[t]{2}{*}{ Genotype } & 0 & 34 & $45.3 \%$ & 0.967 & \pm 0.151 & 0.970 & \pm 0.138 & 1.144 & \pm 0.163 & 1.130 & \pm 0.150 \\
\hline & $1+2$ & 41 & $54.7 \%$ & 0.993 & \pm 0.141 & 0.990 & \pm 0.137 & 1.192 & \pm 0.157 & 1.203 & \pm 0.148 \\
\hline Significance & & & & \multicolumn{2}{|c|}{$P=0.448$} & \multicolumn{2}{|c|}{$P=0.552$} & \multicolumn{2}{|c|}{$P=0.204$} & \multicolumn{2}{|c|}{$P=0.049$} \\
\hline
\end{tabular}


Table 7. Association analysis of haplotype Px of ESR1 gene with BMD for FN and LS.

\begin{tabular}{|c|c|c|c|c|c|c|c|c|c|c|c|}
\hline \multirow{2}{*}{\multicolumn{2}{|c|}{$\begin{array}{l}\text { ESR1 Px } \\
\text { Dose effect of haplotype }\end{array}$}} & \multicolumn{2}{|c|}{$\begin{array}{l}\text { Number of } \\
\text { samples } \\
\text { (n) }\end{array}$} & \multicolumn{2}{|c|}{$\begin{array}{l}\text { Non-adjusted BMD } \\
\text { value for FN } \\
\left(\mathrm{g} / \mathrm{cm}^{2}\right)\end{array}$} & \multicolumn{2}{|c|}{$\begin{array}{l}\text { Adjusted BMD } \\
\text { value for FN } \\
\left(\mathrm{g} / \mathrm{cm}^{2}\right) \\
\end{array}$} & \multicolumn{2}{|c|}{$\begin{array}{l}\text { Non-adjusted BMD } \\
\text { value for LS } \\
\left(\mathrm{g} / \mathrm{cm}^{2}\right)\end{array}$} & \multicolumn{2}{|c|}{$\begin{array}{l}\text { Adjusted BMD value } \\
\text { for } \mathrm{LS}^{2} \\
\left(\mathrm{~g} / \mathrm{cm}^{2}\right)\end{array}$} \\
\hline & & $\mathrm{n}=$ & & & & & & & & & \\
\hline \multirow[t]{3}{*}{ Haplotype dose } & 0 & 58 & $77.3 \%$ & 0.985 & \pm 0.152 & 0.983 & \pm 1.131 & 1.176 & \pm 0.157 & 1.176 & \pm 0.146 \\
\hline & 1 & 17 & $22.7 \%$ & 0.967 & \pm 0.123 & 0.975 & \pm 0.134 & 1.150 & \pm 0.173 & 1.151 & \pm 0.148 \\
\hline & 2 & 0 & $0.0 \%$ & & & & & & & & \\
\hline Significance & & & & \multicolumn{2}{|c|}{$P=0.643$} & \multicolumn{2}{|c|}{$P=0.831$} & \multicolumn{2}{|l|}{$P=0.558$} & \multicolumn{2}{|c|}{$P=0.546$} \\
\hline
\end{tabular}

\begin{tabular}{|c|c|c|c|c|c|c|c|c|c|c|c|}
\hline \multicolumn{12}{|c|}{ Effects of recessiveness and dominance } \\
\hline \multirow[t]{2}{*}{ Genotype } & $0+1$ & 75 & $100.0 \%$ & & & & & & & & \\
\hline & 2 & 0 & $0.0 \%$ & & & & & & & & \\
\hline \multicolumn{12}{|l|}{ Significance } \\
\hline \multirow[t]{2}{*}{ Genotype } & 0 & 58 & $77.3 \%$ & 0.985 & \pm 0.152 & 0.983 & \pm 0.131 & 1.176 & \pm 0.157 & 1.176 & \pm 0.146 \\
\hline & $1+2$ & 17 & $22.7 \%$ & 0.967 & \pm 0.123 & 0.975 & \pm 0.134 & 1.150 & \pm 0.173 & 1.151 & \pm 0.148 \\
\hline Significance & & & & $P=0.6$ & & $P=0.8$ & & $P=0.5$ & & $P=0.5$ & \\
\hline
\end{tabular}

study resulted from an excess of active thyroid hormones and ESR1 polymorphisms, while the protective effect of estrogens on bone was maintained.

The lower BMD values in GD women is a consequence of hyperthyroidism leading to higher bone turnover and accelerated bone loss. Bone loss induced by hyperthyroidism is usually reversible, but achieving euthyreosis does not restore bone quality immediately. The recovery of balance between bone formation and resorption takes 7.5 to 12 months from the TSH normalization and this period is usually sufficient to increase BMD value (Jodar et al., 1997; Horst-Sikorska et al., 2005). Much earlier, just after 6 months, the biochemical markers of bone metabolism reach normal values (Diamond et al., 1994). No significant correlation between the duration of hyperthyroidism remission and improvement of BMD was observed in the studied females with GD. However, higher BMD values in both lumbar spine and femoral neck were found in females euthyreotic for more than 1 year, which suggests sufficiency of bone repair processes after normalization of thyroid function.

Hyperthyroidism causes an increase of osteoclastic resorption particularly in the cortical bone, so loss of cortical bone is characteristic for hyperthyroidism-related osteoporosis (Hofbauer et al., 1999; Greenspan et al., 1999; Lakatos 2003). High prevalence of cortical bone loss was noticed by Majima et al. (2006a) in GD male patients. Those authors paid special attention to BMD measurements and its monitoring as crucial in Graves' patients, irrespectively of gender and age (Majima et al., 2006a; 2006b).

We did not corroborate this. The low frequency of osteoporosis in the studied women defined as T-score $<-2.5 \mathrm{SD}$ was probably related to the fact that the study involved regularly menstruating women in whom

Table 8. Association analysis of ESR1 polymorphisms (Pvull, Xbal) with Graves' disease

\begin{tabular}{|c|c|c|c|c|c|c|c|c|}
\hline & & \multicolumn{7}{|c|}{ Genotype frequency } \\
\hline \multirow{2}{*}{\multicolumn{2}{|c|}{ ESR1 polymorphisms }} & \multicolumn{4}{|c|}{ Controls } & \multicolumn{3}{|c|}{$\mathrm{GD}$} \\
\hline & & \multirow{2}{*}{\multicolumn{2}{|c|}{$\begin{array}{l}n \\
n=163\end{array}$}} & \multirow{2}{*}{$\begin{array}{l}n \\
n=75\end{array}$} & \multirow[t]{2}{*}{$\%$} & \multicolumn{3}{|c|}{ Effects of recessiveness and dominance } \\
\hline ESR1 Pvull & & & & & & & d.f. $=1$ & \\
\hline \multirow[t]{3}{*}{ Genotype } & PP & 43 & 26.4 & 13 & 17.3 & $\mathrm{PP}$ vs $\mathrm{Pp}+\mathrm{pp}$ & $c 2=2.34$ & $P=0.126$ \\
\hline & $\mathrm{Pp}$ & 78 & 47.9 & 41 & 54.7 & & & \\
\hline & $\mathrm{pp}$ & 42 & 25.8 & 21 & 28.0 & $\mathrm{pp}$ vs $\mathrm{Pp}+\mathrm{PP}$ & $c 2=0.13$ & $P=0.717$ \\
\hline \multicolumn{2}{|c|}{ Pearson's $\chi 2$} & \multicolumn{2}{|c|}{$c 2=2.36$} & d.f. $=2$ & $P=0.307$ & & & \\
\hline \multicolumn{2}{|c|}{ Armitage's $\chi 2$ trend test } & \multicolumn{2}{|c|}{$c 2=1.31$} & d.f. $=1$ & $P=0.253$ & & & \\
\hline \multicolumn{2}{|l|}{ ESR1 Xbal } & \multicolumn{2}{|c|}{$\mathrm{n}=163$} & \multicolumn{2}{|l|}{$\mathrm{n}=75$} & & d.f. $=1$ & \\
\hline \multirow[t]{3}{*}{ Genotype } & $x X$ & 14 & 8.6 & 9 & 12.0 & $X X$ vs $X x+x x$ & $c 2=0.68$ & $P=0.408$ \\
\hline & $\mathrm{Xx}$ & 84 & 51.5 & 32 & 42.7 & & & \\
\hline & $x x$ & 65 & 39.9 & 34 & 45.3 & $x x$ vs $X x+X X$ & $c 2=0.63$ & $P=0.428$ \\
\hline \multicolumn{2}{|c|}{ Pearson's $\chi 2$} & \multicolumn{2}{|c|}{$c 2=1.82$} & d.f. $=2$ & $P=0.404$ & & & \\
\hline \multicolumn{2}{|c|}{ Armitage's $\chi 2$ trend test } & \multicolumn{2}{|c|}{$c 2=0.05$} & d.f. $=1$ & $P=0.819$ & & & \\
\hline
\end{tabular}


Table 9. Frequency of px, PX, Px haplotypes of ESR1 gene in patients with Graves' disease and in controls

\begin{tabular}{|c|c|c|c|c|c|}
\hline & & \multicolumn{4}{|c|}{ Haplotype frequency } \\
\hline & & \multicolumn{2}{|c|}{ Controls } & \multicolumn{2}{|l|}{ GD } \\
\hline & & $n$ & $\%$ & $\mathrm{n}$ & $\%$ \\
\hline \multirow{2}{*}{ Haplotype } & $\mathrm{px}$ & 162 & 49.7 & 83 & 55.3 \\
\hline & Remaining & 164 & 50.3 & 67 & 44.7 \\
\hline \multicolumn{2}{|l|}{ Pearson's $\chi 2$} & $c 2=1.3$ & d.f. $=1$ & \multicolumn{2}{|c|}{$P=0.253$} \\
\hline \multicolumn{2}{|c|}{ Odds ratio } & $\mathrm{OR}=0.8$ & \multicolumn{3}{|c|}{$95 \% \mathrm{Cl}$ [ 0.54-1.18] } \\
\hline \multirow[t]{2}{*}{ Haplotype } & $\mathrm{PX}$ & 112 & 34.4 & 50 & 33.3 \\
\hline & Remaining & 214 & 65.6 & 100 & 66.7 \\
\hline \multicolumn{2}{|c|}{ Pearson's $\chi 2$} & $c 2=0.05$ & d.f. $=1$ & \multicolumn{2}{|c|}{$P=0.827$} \\
\hline \multicolumn{2}{|c|}{ Odds ratio } & $\mathrm{OR}=1.05$ & \multicolumn{3}{|c|}{$95 \% \mathrm{Cl}[0.70-1.58]$} \\
\hline \multirow[t]{2}{*}{ Haplotype } & Px & 52 & 16.0 & 17 & 11.3 \\
\hline & Remaining & 274 & 84.0 & 133 & 88.7 \\
\hline \multicolumn{2}{|c|}{ Pearson's $\chi 2$} & $c 2=1.77$ & d.f. $=1$ & \multicolumn{2}{|c|}{$P=0.184$} \\
\hline \multicolumn{2}{|c|}{ Odds ratio } & $\mathrm{OR}=1.49$ & \multicolumn{3}{|c|}{$95 \% \mathrm{Cl}[0.83-2.67]$} \\
\hline
\end{tabular}

and the BMD values was negative. Effect of recessiveness was found for the pp genotype. The lumbar BMD in women homozygous for the $\mathrm{p}$ allele was significantly decreased, while $\mathrm{P}$ allele carriers had higher values of LS BMD. A possible explanation for BMD reduction, despite a lack of estrogens deficit, is that $\mathrm{p}$ and $\mathrm{x}$ alleles of ESR1 somewhow determine weaker biological impact of estrogens on bone. In these women an excess of thyroid hormones may lead to more intense bone resorption than in the $\mathrm{P}$ and $\mathrm{X}$ alleles carriers.

The association of BMD with ESR1 genotypes has been identified in several studies (Kobayashi et al., 1996; Mahonen et al., 1997; Willing et al., 1998). Authors of those reports emphasize that the genotype that predicts low or high bone mineral density may be population specific. Indeed, Japanese women with the PP genotype had lower BMD while in American and Finnish females decreased bone mineral density was estrogen secretion ensured efficient bone remodeling. It is interesting, as although cortical bone is more metabolically active, and thus more prone to factors decreasing bone mass, no significant changes contrary to trabecular bone - were observed. Probably remodeling processes in cortical bone were more effective or duration of thyrotoxicosis was too short to disturb bone metabolism considerably. We hypothesize, that in our study group sufficient action of estrogens was a strong protective factor on bone and eliminated negative influence of thyroid hormones' excess.

Only a few studies have been published on the expression of TSHR in human bone cells or on the influence of serum TSH on bone parameters. Direct effect of TSH on BMD, independent of thyroid hormones' level, was found recently by Heemstra et al. (2008). Van der Deure et al. (2008) found a stronger effect of fT4 than TSH on BMD. They noticed that femoral neck BMD increased with serum TSH level (van der Deure et al., 2008). A recent cross-sectional study by Baqi et al. (2010) confirmed the role of TSH in bone metabolism. A highly significant influence of TSH on BMD at FN and LS independent of age was found. Patients with normal TSH level had favorable bone status while women with low level of TSH had lower BMD. Those authors concluded that the impact of THS on BMD may be substantial. That study was conducted in 113 postmenopausal women, including GD patients, so the conclusions should be carefully compared with our results. The question what causes differences in the bone status among patients with GD was addressed in an analysis of polymorphic variants of selected genes, the function of their protein products and literature data on osteoporosis in GD (Walker-Bone et al., 2002; Lakatos, 2003).

We confirmed the association between LS BMD and the allelic variants of ESR1 polymorphisms (PvuII, $\mathrm{XbaI}$ ). A dose effect was observed for allele $\mathrm{x}$ of $\mathrm{Xba \textrm {I }}$. Women homozygous for $\mathrm{xx}$ had the lowest mean BMD adjusted for age, body mass and height as compared to $\mathrm{Xx}$ heterozygotes and $\mathrm{XX}$ homozygotes. This was true for the lumbar bone, but not for femoral neck. In turn, the correlation between $\mathrm{p}$ allele dose of PvuII associated with the pp genotype. A multicenter study by Ioannidis et al. (2004) performed on 18917 patients from eight European centers did not confirm any relation of PvuII polymorphism with BMD and risk fracture. In turn patients with XX genotype of XbaI had a slightly higher FN BMD and reduced fracture risk. The relationship between $\mathrm{xx}$ genotype and low BMD was documented also by Willing et al. (1998)

The present study also indicated a recessive effect for the px haplotype of the ESR1 gene. Women with two copies of the px haplotype had the lowest lumbar BMD compared to patients without or with only one copy of this haplotype. This rule was observed for adjusted bone mineral density at LS. PX homozygotes had the highest adjusted LS BMD while non-carriers of this haplotype had the lowest non- and adjusted LS BMD. There was no influence of any haplotype of ESR1 on BMD at femoral neck.

In studies on postmenopausal women with hyperthyroidism estrogen deficiency which definitely has a strong impact on bone turnover, was an important factor.

In our study premenopausal women presenting normal estrogen level were shown to have different BMD values depending on the ESR1 haplotype. The ESR1 px variant was shown to predispose to increased bone resorption and the lowest values of lumbar BMD. This observation could indicate yet another genetic risk factor for osteoporosis and help identify women with hyperthyroidism particularly predisposed to secondary osteoporosis. Our results are partly consistent with published data. There is some convincing evidence on the 19 association between ESR1 px haplotype and lower bone mineral density (Colin et al., 2003; van Meurs et al., 2003; Zhang et al., 2003). It should also be noticed that more publications report a relationship between the Px rather than the px haplotype with low BMD (Kobayashi et al., 1996; Albagha et al., 2001). An analysis of PvuII and XbaI polymorphisms of ESR1 in British subjects reported an association between Px haplotype and decreased BMD (Albagha et al., 2001). A Chinese study revealed association between PX haplotype and low spine 
mineral density while PX carriers had decreased hip BMD (Zhang et al., 2003). However, other studies that showed no associations between the polymorphic variants of ESR1 and BMD (Gennari et al., 1998; Bechereni et al., 2000; Yamada et al., 2002). Yamada et al. (2002) found no differences in bone mineral density among Japanese women under 60 years regarding the PvuII and XbaI genotypes. Bechereni et al. (2000) made the same observations for Italian women. This conflicting observations may result from a diverse distribution of the polymorphisms in populations, and the impact of environmental factors such as dietary habits, physical activity and exposure to sunlight.

Our results show that none of the polymorphic variants of the ESR1 gene was particularly responsible for the development of Graves' disease despite the well documented role of estrogens in human autoimmunity. There were no statistically significant differences in the frequency of particular polymorphic alleles of ESR1 and their haplotypes between patients with GD and controls. These results are consistent with previous studies (Ban et al., 2000; 2001). Also Japanese and Russian populations were studied for the predisposition to Graves' disease in relation to human estrogen receptor alpha and beta genes' microsatellite polymorhisms, with no associations between ESR1 (alpha) or ESR2 (beta) and autoimmune thyroid diseases being found (Ban et al., 2001; Chistiakov et al., 2002).

In view of the above inconsistencies between studies, our results should be interpreted with caution. Osteoporosis is a complex multigenic disease. Moreover, multiple factors and metabolic processes are involved in bone turnover and bone quality, that are in part independent of the genetic makeup of individuals. Beside BMD measured by DEXA, bone geometry, its architecture and various other parameters influence bone strength. These factors should also be considered in estimation of osteoporosis risk. Our study focused on the association between the PvuII and XbaI polymorphisms of the ESR1 gene and bone mineral density in premenopausal women with GD. The results suggest that estrogen receptor alpha gene may have important influence on bone mineral density in these patients, particularly at lumbar spine. The main limitation of the study was small sample size. The observed associations may represent a true trend that might be population-specific. However, further large-scale investigations are required to confirm the evidence of ERS1 gene linkage to BMD and to clarify whether its polymorphisms may be applicable as genetic markers of osteoporosis prediction among women with Graves' disease.

\section{CONCLUSIONS}

1. Analysis of PvuII and XbaI polymorphisms of ESR1 gene may be considered to estimate the risk of osteoporosis in premenopausal Polish women with GD because:

- homozygotes: xx of XbaI and pp of PvuII were shown to have reduced bone mineral density at the lumbar spine

- px haplotype predisposed to lower lumbar spine BMD.

2. ESR1 gene polymorphisms do not predict the risk of Graves' disease in Polish female patients.

\section{REFERENCES}

Albagha OM, McGuian FE, Reid DM, Ralston SH (2001) Estrogen receptor alpha gene polymorphisms and bone mineral density: haplotype analysis in women from the United Kingdom. I Bone Miner Res 16: 128-134.

Ban Y, Taniyama M, Tozaki T, Tomita M, Ban Y (2000) Estrogen receptor alpha dinucleotide repeat polymorphism in Japanese patients with autoimmune thyroid diseases. BMC Med Genet 1: 1.

Ban Y, Tozaki T, Taniyama M, Tomita M, Ban Y (2001) Lack of association between estrogen receptor beta dinucleotide repeat polymorphism and autoimmune thyroid diseases in Japanese patients. BMC Med Genet 2: 1

Baqi L, Payer J, Killinger Z, Susienkova K, Jackuliak P, Cierny D, Langer P (2010) The level of TSH appeared favorable in maintaining bone mineral density in postmenopausal women. Endocr Regul 44: 9-15.

Bechereni L, Gennari L, Masi L, Mansani R, Massart F, Morelli A, Falchetti A, Gonnelli S, Fiorelli G, Tanini A, Brandi ML (2000) Evidence of a linkage disequilibrium between polymorphisms in the human estrogen alpha gene and their relationship to bone mass variation in postmenopausal Italian women. Hum Mol Genet 9: 2043-2050.

Chistiakov DA, Savost'anov KV, Turakulov RI, Petunina N, Balabolkin MI, Nosikov VV (2002) Further studies of genetic susceptibility to Graves' disease in a Russian population. Med Sci Monit 8: 180-184.

Colin E, Uitterlinden A, Meurs J, Bergink AP, van de Klift M, Fang Y, Arp PP, Hofman A, van Leeuwen JP, Pols HA (2003) Interaction between vitamin $\mathrm{D}$ receptor genotype and estrogen receptor alpha genotype influences vertebral fracture risk. I Clin Endocrinol Metab 88: $3777-3784$.

Cutolo M, Sulli A, Seriolo B, Accardo S, Masi AT (1995) Estrogens, the immune response and autoimmunity. Clin Exp Rheumatol 13: 217-226.

van der Deure WM, Uitterlinden AG, Hofman A, Rivadeneira F, Pols HA, Peeters RP, Visser TJ (2008) Effects of serum TSH and FT4 levels and the TSHR-Asp727Glu polymorphism on bone: the Rotterdam Study. Clin Endocrinol (Oxf) 68: 175-81.

Diamond T, Vine J, Smart R, Butler P (1994a) Thyrotoxic bone disease in women: a potentially reversible disorder. Ann Intern Med 128: 8-11.

Diamond T, Vine J, Smart R (1994) Thyrotoxic bone disease in women: a potentially reversible disorder. Ann Intern Med 120: 8-21.

Donner H, Rau H, Walfish PJ Braun T, Siegmund R, Finke J, Herwig KH, Usadel, Badenhoop K (1997) CTLA-4 alanine-17 confers genetic susceptibility to Graves' disease and to type 1 diabetes mellitus. J Clin Endocrinol Metab 82: 143-146.

Eriksen EF, Mosekilde L, Melsen F (1995) Trabecular bone remodeling and bone balance in hyperthyroidism. Bone 6: 421-428.

Gennari L, Becherini L, Masi L, Mansani R, Gonnelli S, Cepollaro C, Martini S, Montagnani A, Lentini G, Becorpi AM, Brandi ML (1998) Vitamin D and estrogen receptor allelic variants in Italian postmenopausal women: evidence of multiple gene contribution to bone mineral density. J Clin Endocrinol Metab 83: 939-944.

Greenspan S, Greenspan F (1999) The effect of thyroid hormone on skeletal integrity. Ann Intern Med 130: 750-758.

Heemstra KA, van der Deure WM, Peeters RP, Hamdy NA, Stokkel MP, Corssmit EP, Romijn JA, Visser TJ, Smit JW (2008) Thyroid hormone independent associations between serum TSH levels and indicators of bone turnover in cured patients with differentiated thyroid carcinoma. Eur J Endocrinol 1: 69-76.

Hofbauer L, Khosla S, Dunstan CR, Lacey DL, Spelsberg TC, Riggs BL (1999) Estrogen stimulates gene expression and protein production of osteoprotegerin in human osteoblastic cells. Endocrynol 140: 4367-4370.

Horst-Sikorska W (2005) Hyperthyroidism in metabolic disorders of bone. Badurski J, Borgis, eds, pp 210-216, Warszawa (in Polish).

Horst-Sikorska W, Ignaszak-Szczepaniak M, Marcinkowska M, Stajgis M, Kaczmarek M, Slomski R (2008) Association analysis of vitamin $\mathrm{D}$ receptor gene polymorphisms with bone mineral density in young women with Graves' disease. Acta Bioch Pol 55: 371-380.

Horst-Sikorska W, Wawrzyniak A, Celczynska-Bajew L (2005) Polymorphism of VDR gene - the most effective molecular marker of osteoporotic bone fractures risk within postmenopausal women from Wielkopolska region of Poland. Endokrynol Pol 56: 233-239 (in Polish)

Ioannidis JP, Stavrou I, Trikalinos TA, Zois C, Brandi ML, Gennari L, Albagha O, Ralston SH, Tsatsoulis A (2002) Association of polymorphisms of the estrogen receptor alpha gene with bone mineral density and fracture risk in women: a metaanalysis. $J$ Bone Miner Res 17: 2048-2060.

Ioannidis JP, Ralston SH, Bennett ST, Brandi ML, Grinberg D, Karassa FB, Langdahl B, van Meurs JB, Mosekilde L, Scollen S, Albagha OM, Bustamante M, Carey AH, Dunning AM, Enjuanes A, van Leeuwen JP, Mavilia C, Masi L, McGuigan FE, Nogues X, Pols HA, Reid DM, Schuit SC, Sherlock RE, Uitterlinden AG; 
GENOMOS Study (2004) Differential genetic effects of ESR1 gene polymorphisms on osteoporosis outcomes. JAMA 292: 2105-2114.

Jodar E, Munoz-Torres M, Escobar-Jiminez F (1997) Bone loss in hyperthyroid patients and in former hyperthyroid controlled on medical therapy: influence of aetiology and menopause. Clin Endocrinol (Oxf) 47: 279-285.

Kanis JA on behalf of the World Health Organisation Scientific Group (2007) Assessment of osteoporosis at the primary health care level. Technical Report. World Health Organisation Collaborating Centre for Metabolic Bone Disease, University of Sheffield, UK, 2007. Printed by the University of Sheffield.

Kobayashi S, Inoue S, Hosoi T, Ouchi Y, Shiraki M, Orimo H (1996) Association of bone mineral density with polymorphism of the estrogen receptor gene. J Bone Miner Res 11: 306-311.

Lakatos P (2003) Thyroid hormones: beneficial or deleterious for bone? Calcif Tissue Int 73: 205-209.

Mahonen A, Turunen AM, Kroger H, Maempaa PH (1997) Estrogen receptor gene polymorphism is associated with bone mineral density in perimenopausal Finnish women. J Bone Miner Res 12: T614.

Majima T, Komatsu Y, Doi K, Takagi C, Shigemoto M, Fukao A, Morimoto T, Corners J, Nakao K (2006a) Clinical significance of risedronate for osteoporosis in the initial treatment of male patients with Graves' disease. J Bone Miner Metab 24: 105-113.

Majima T, Komatsu Y, Doi K, Takagi C, Shigemoto M, Fukao A, Morimoto T, Corners J, Nakao K (2006b) Negative correlation between bone mineral density and TSH receptor antibodies in male patients with untreated Graves' disease. Osteoporosis Int 17: 11031110. van Meurs JB, Schuit SC, Weel AE, van der Klift M, Bergink AP, Arp PP, Colin EM, Fang Y, Hofman A, van Duijn CM, van Leeuwen JP, Pols HA, Uitterlinden AG (2003) Association of 5'-estrogen receptor alpha gene polymorphisms with bone mineral density, vertebral bone area and fracture risk. Hum Mol Genet 12: 1745-1754. Murphy E, Wiliams GR (2004) The thyroid and skeleton. Clin Endocrinol 61: 285-298.

Walker-Bone K, Walter G, Cooper C (2002) Recent developments in the epidemiology of osteoporosis. Curr Opin Rheumatol 14: 411-415.

Willing M, Sowers M, Aron D, Clark D, Burns T, Bunten C, Crutchfield M, D'Agostino D, Jannausch M (1998) Bone mineral density and its change in white women: estrogen and vitamin D receptor genotypes and their interaction. J Bone Miner Res 13: 695705.

Yaich L, Dupont WD, Cavener DR, Parl FF (1992) Analysis of the PvuII restriction fragment-length polymorphism and exon structure of the estrogen receptor gene in breast cancer and peripheral blood. Cancer Res 52: 77-78.

Yamada Y, Ando F, Niino N, Ohta S, Shimokata H (2002) Association of polymorphisms of the estrogen receptor alpha gene with bone mineral density of the femoral neck in elderly Japanese women. $J$ Mol Med 80: 452-460.

Zhang Y, Long J, Liu P, Liu YJ, Shen H, Zhao LJ, Deng HW (2003) Estrogen receptor alpha and vitamin D receptor polymorphisms and bone mineral density: association study of healthy pre- and postmenopausal Chinese women. Biochem Biophys Res Commun 308: $777-783$. 